\title{
Thoracic trident pigmentation in Drosophila melanogaster : Differentiation of geographical populations
}

\author{
J.R. DAVID *, P. CAPY *, Véronique PAYANT * \\ and S. TSAKAS ** \\ * C.N.R.S., Laboratoire de Biologie et Génétique évolutive \\ F 91190 Gif-sur-Yvette \\ ** Department of Genetics, Agricultural College \\ Athens, Greece
}

\begin{abstract}
Summary
A phenotypic classification of trident pigmentation allowed the characterization of any natural population by a pigmentation score, ranging from 0 to 3 . After some training, independent observers could produce very similar score values. Growth temperature influences pigmentation intensity and the response curves exhibit a U-shape, with a minimum at about $25^{\circ} \mathrm{C}$. For the description of natural populations, 2 different growth temperatures, $17^{\circ} \mathrm{C}$ and $25^{\circ} \mathrm{C}$ were chosen. Crosses between a dark French strain and a light Afrotropical strain produced intermediate offspring, but a clear maternal effect differentiated the reciprocal Fl's. Numerous populations from various part of the world were investigated and results arranged according to the latitude. For temperate populations collected between 34 and $48^{\circ}$ of latitude a steep cline was observed (pigmentation being much more darker in high latitude) suggesting an adaptive pressure on this phenotype : environmental factors which may explain this cline being temperature, insolation and desiccation. In tropical populations on the other hand a large variability was observed but without any relation to latitude.
\end{abstract}

Key words : Drosophila melanogaster, pigmentation, temperature response, maternal effect, latitudinal cline.

\section{Résumé \\ La pigmentation thoracique en forme de trident chez Drosophila melanogaster : différenciation de populations de diverses origines géographiques}

Une classification phénotypique de la pigmentation du trident thoracique a permis de caractériser une population naturelle par un score de pigmentation, variant entre 0 et 3 . Après un certain entraînement, des observateurs indépendants ont pu obtenir des scores très voisins. La température de développement modifie l'intensité de la pigmentation et les courbes de réponses ont une forme en $\mathrm{U}$, avec un minimum aux environs de $25^{\circ} \mathrm{C}$. Deux températures de développement, 17 et $25^{\circ} \mathrm{C}$, ont été choisies pour la description des populations naturelles. Le croisement entre une souche française sombre et une souche afrotropicale claire a produit des descendants intermédiaires, mais un effet maternel net différencie les Fl réciproques. De nombreuses populations de diverses régions du globe ont été étudiées et les résultats analysés en fonction de la latitude. Pour des populations tempérées, récoltées entre 34 et $48^{\circ}$ de latitude, un cline abrupt a été observé (la pigmentation est bien plus sombre aux 
latitudes élevées), suggérant une signification adaptative de ce phénotype. Les facteurs de l'environnement qui peuvent expliquer ce cline sont la température, l'insolation et la dessication. Dans les populations tropicales, au contraire, une grande variabilité a été observée mais sans relation avec la latitude.

Mots clés : Drosophila melanogaster, pigmentation thoracique, réponse à la température, effet maternel, cline latitudinal.

\section{Introduction}

Drosophila melanogaster strains and populations have been known for a long time to be polymorphic, for the occurence of a dark pigmented area on the thorax, with a general trident pattern (see fig. 1). MorgAN \& BRIDGES (1919) already paid some attention to the inheritance of this pigmentation. DubININ and his collaborators, in 1934, investigating the genetic variability of natural populations, also considered this phenotypic variation but found it difficult to analyse genetically (cited in Merrell, 1981 p. 30). A trident gene (tr, 2-55) was described by Plough \& Ives in 1934 (LINDSLEY \& GRELl, 1968). At about the same date another gene, pentagon (ptq, 1-23.2) was located on the X chromosome (see also LindSLEY \& GRELL, 1968). More recently, JACOBS (1978), studying the inheritance of a dark trident on the thorax, concluded « darkening appears mainly caused by chromosome 3 , with enhancement by chromosome $2 »$. Other genes which, like ebony or black, increase the darkness of the whole body, are also known to enhance the expression of the trident pattern.

Thoracic trident in natural populations appears therefore as a quantitative trait with a complex genetic basis. Moreover the intensity of the pigmentation, in contrast with other quantitative traits such as wing length or chaetae number, is difficult to measure. This difficulty presumably explains why so few papers have addressed its biochemical determination and possible adaptive significance (JACOBS, 1960 ; $1974 ; 1976 ; 1982)$.

Drosophila melanogaster is also the most differentiated species with respect to its geographic distribution (see LemEunIER et al., 1985, for a review). During a comparison of temperate and tropical populations for genetical traits like allozyme frequencies, morphology or physiology (DAvid \& BocouET, 1975 ; DAvID et al., 1977 ; DAvID, 1982 ; CAPY et al., 1983) it was noticed that populations in the tropics are generally lighter than those living in France. This observation seemed particularly interesting since latitudinal variations in pigmentation occur in many animal species and because the adaptative significance of pigmentation has been repeatedly disccussed in the context of Gloger's rule (RENSCH, 1960 ; MAYR, 1963 ; DobZHANSKY, 1970 ; MERREL, 1981).

We decided to study the phenotypic and genetic variability of trident pigmentation in geographically distant populations of $D$. melanogaster. After several assays a convenient technique was worked out to estimate the average pigmentation of a natural population reared under controlled conditions. The temperature response curve of the pigmentation intensity has been worked out and a cross between a light and a dark strain showed a clear maternal effect between reciprocal Fl's. We also found a latitudinal cline (between 30 and $48^{\circ}$ of latitude), but the geographic pattern is quite different from those observed for other previously described characters. 


\section{Materials and methods}

\section{A. Drosophila populations}

Since all quantitative traits will undergo genetic drift in the laboratory (DAvID, 1979) the following procedure was used to estimate the phenotypic characteristics of a natural population. Wild collected females were isolated into rearing vials to initiate isofemale lines. Samples of adults of the various lines were then put together to make a mixed, mass population. In almost all cases the number of founder lines was greater than 15. The mixed adults were then allowed to oviposit for $24 \mathrm{~h}$ in a culture bottle containing a killed yeast medium (DAVID \& CLAVEL, 1965). The bottles were then transferred to the rearing temperature, generally 17 or $25^{\circ} \mathrm{C}$. After emergence, the adults were placed on fresh food for a few days and then scored for intensity of trident pigmentation.

\section{B. Calibration of the trident phenotypic score}

Because of the small size of the flies, any physical method of measuring the pigmentation of the thorax or the reflectance of the cuticle seemed impracticable. It appeared on the other hand, that a qualitative visual examination of the individuals would allow a separation into phenotypic classes, as has already been done by Morgan \& Bridges (1919). After several attempts, it was decided to use only 4 classes, which are drawn in figure 1 . They are :

Class 0 : no visible trident

Class 1 : faint trident

Class 2 : trident clearly marked

Class 3 : dark trident

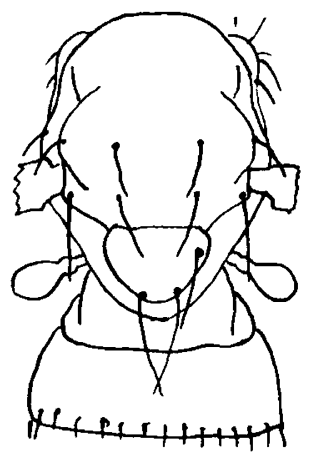

0

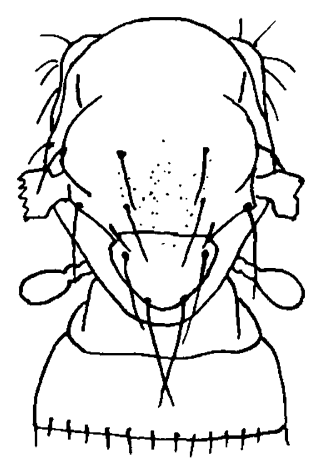

1

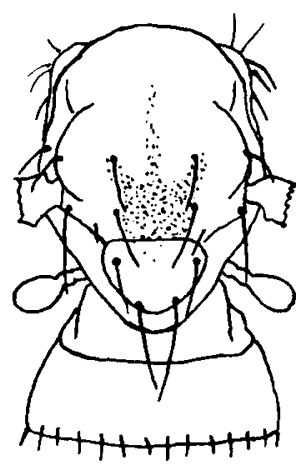

2

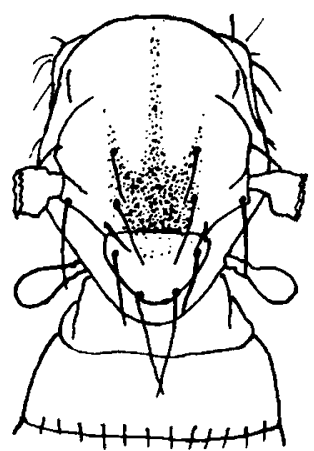

3

FIG, 1

The 4 phenotypic classes used to measure the intensity of trident pigmentation. Les 4 classes phénotypiques'utilisées pour mesurer l'intensité de la pigmentation du trident. 
$25^{\circ} \mathrm{C}$

$17^{\circ} \mathrm{C}$

\section{Villeurbanne}
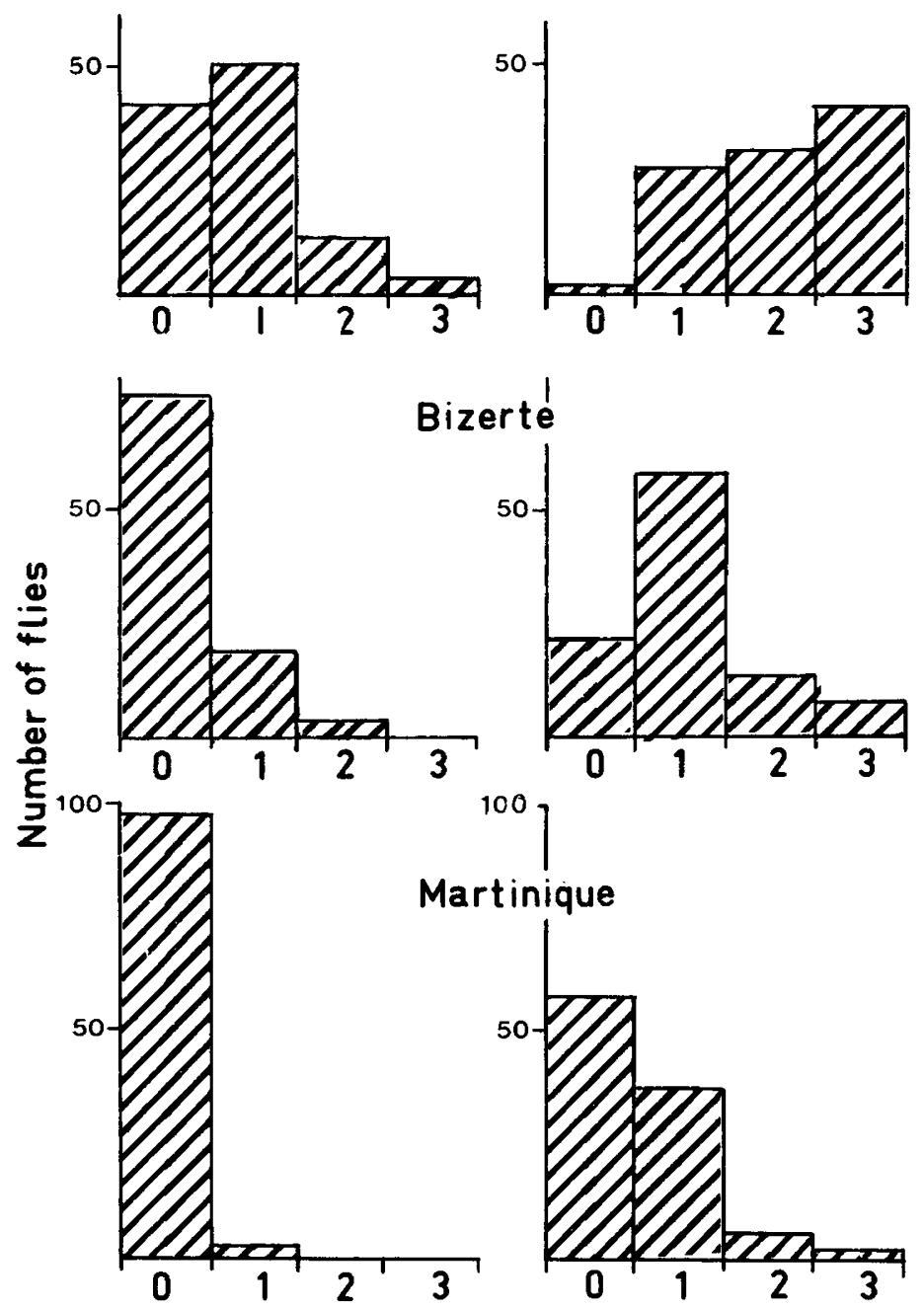

rte
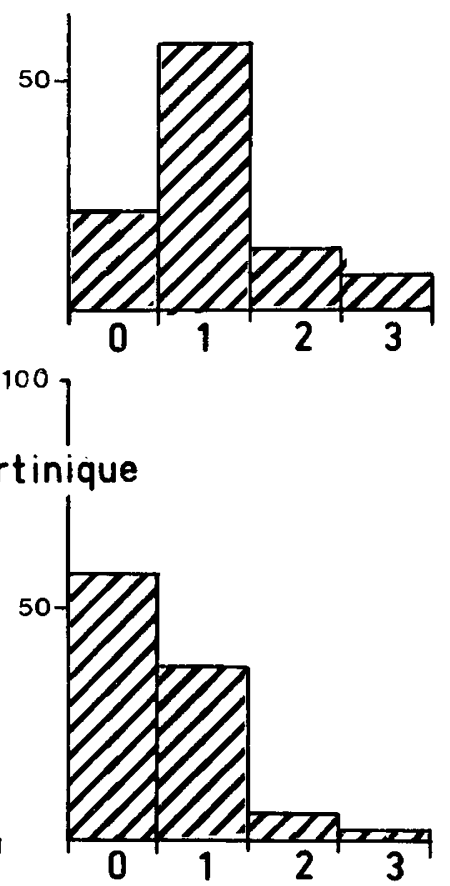

Pigmentation: Phenotypic classes

FIG. 2

Examples of frequency distributions of trident phenotypic classes for 3 different geographic populations grown either at 17 or $25^{\circ} \mathrm{C}$.

Exemples de distributions de fréquences des classes phénotypiques du trident pour 3 populations d'origines différentes élevées à 17 ou à $25^{\circ} \mathrm{C}$. 
Examples of the distributions of the flies among these four classes are given in figure 2 for several populations. The major problem was to obtain repeatable distributions for different samples from the same population and, still more difficult, to get compatible values from different investigators studying the same sample. This was achieved by a progressive training (successive assays by different observers considering independently the same samples and then confronting their results). During this training period it appeared that the shape of the distribution frequencies would remain quite variable between different observers while the phenotypic averages (ranging from 0 to 3 ) were much more concordant. It was finally decided to characterize a population by its mean score obtained on 2 samples of 100 males and 100 females.

An example of the dispersal of the phenotypic scores obtained by 2 observers is given in table 1 for 28 different samples. The maximum divergence $d$ between the score of the same sample was 0.42 . However over the whole study no systematic difference existed since the average value $(d=.01 \pm .05)$ was very close to zero. Moreover, a high correlation $(r=0.96)$ existed between independant observations.

TABLE 1

Calibration of the technique for measuring the pigmentation scores (between 0 and 3) of various populations. For each sample, 100 males or females were studied.

Calibration de la technique utilisée pour établir le score de pigmentation (compris entre 0 et 3) de diverses populations.

Pour chaque échantillon, 100 mâles et 100 femelles ont été étudiés.

\begin{tabular}{|c|c|c|c|c|c|c|c|}
\hline \multirow{2}{*}{ Populations } & \multirow{2}{*}{ Temp. } & \multicolumn{3}{|c|}{ Males } & \multicolumn{3}{|c|}{ Females } \\
\hline & & F.O. & S.O. & $d$ & F.O. & S.O. & $\mathrm{d}$ \\
\hline Draveil & 17 & 2.02 & 1.89 & +0.13 & 2.06 & 1.90 & +0.16 \\
\hline Draveil & 25 & 0.61 & 0.66 & -0.05 & 0.76 & 0.77 & -0.01 \\
\hline Villeurbanne & 17 & 2.16 & 1.92 & +0.24 & 2.09 & 2.00 & +0.09 \\
\hline Villeurbanne .. & 25 & 0.76 & 0.59 & +0.17 & 0.90 & 0.98 & -0.08 \\
\hline Moulis $\ldots \ldots \ldots$ & 17 & 1.86 & 1.54 & +0.32 & 1.92 & 1.51 & +0.41 \\
\hline Athens $\ldots \ldots$ & 25 & 0.40 & 0.21 & +0.19 & 0.49 & 0.36 & +0.13 \\
\hline Porquerolles .... & 17 & 1.61 & 1.60 & +0.01 & 1.56 & 1.51 & +0.05 \\
\hline Barcelone ....... & 17 & 2.18 & 2.10 & +0.08 & 2.14 & 2.17 & -0.03 \\
\hline Barcelona .... & 25 & 1.00 & 1.09 & -0.09 & 1.12 & 1.13 & -0.01 \\
\hline Bizerte.... & 17 & 1.07 & 1.22 & -0.15 & 1.03 & 1.14 & -0.11 \\
\hline Bizerte $\ldots$ & 25 & 0.22 & 0.21 & +0.01 & 0.33 & 0.31 & +0.02 \\
\hline Cotonou ........ & 17 & 0.86 & 0.89 & -0.03 & 1.02 & 1.05 & -0.03 \\
\hline Brazzaville . . . . . & 17 & 0.82 & 1.10 & -0.28 & 0.72 & 1.14 & -0.42 \\
\hline Brazzaville ...... & 25 & 0.11 & 0.19 & -0.08 & 0.11 & 0.43 & -0.32 \\
\hline
\end{tabular}

F.O. : First observer.

S.O. : Second observer.

d : Difference between first and second observer.

Temp. : Temperature. 
We can therefore conclude that with some training, it is possible to estimate the phenotypic score of any sample of Drosophila adults with sufficient acccuracy to allow comparisons between populations.

\section{Results}

\section{A. Temperature response of trident pigmentation}

Temperature of growth influences many adults phenotypic traits (see DAvid et al., 1983 ; for a review) but the variations of body pigmentation has never been conveniently described. It was thus decided first to work out the temperature response

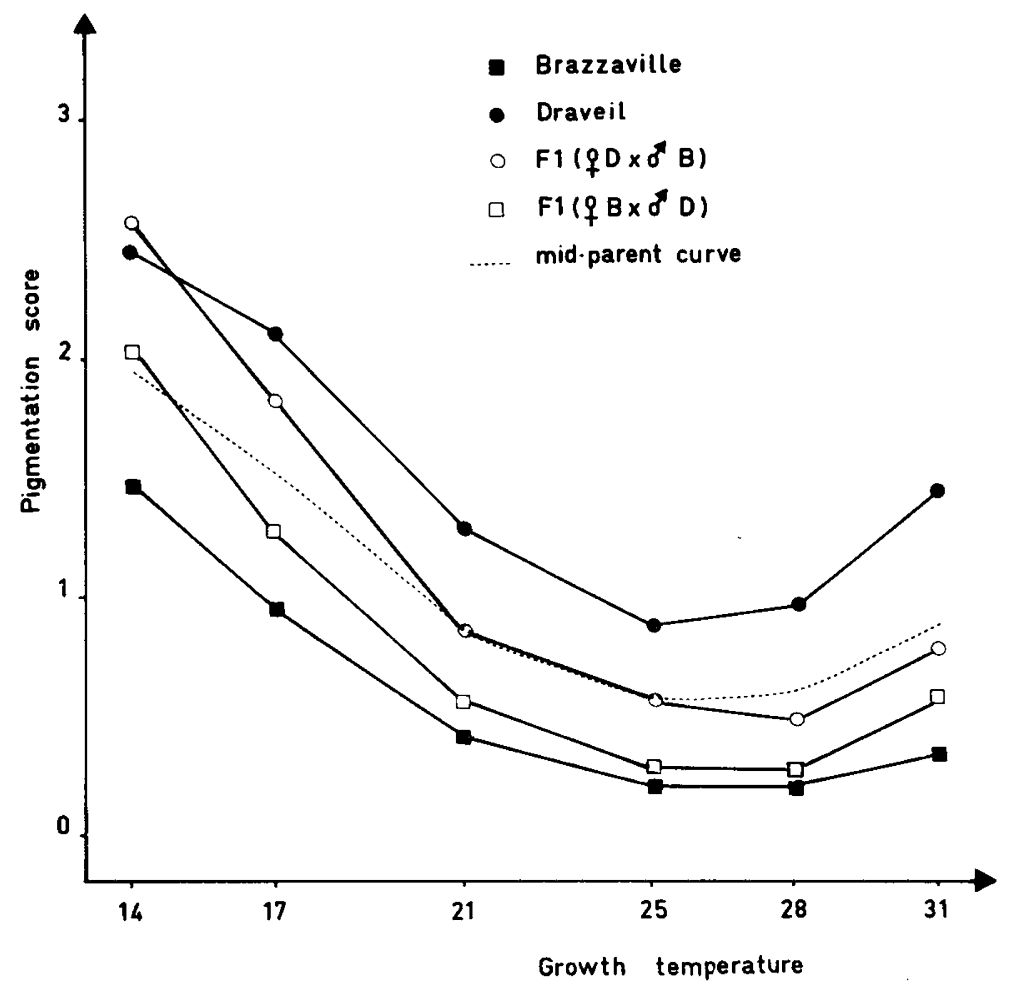

FIG. 3

Temperature response of trident pigmentation of a light (Brazzaville) and a dark (Draveil) population and of their reciprocal Fl. Flies were studied by 3 independent observers. For each genotype and temperature, data of males and females of the different observers were pooled.

Réponse à la température de la pigmentation du trident chez une population claire (Brazzaville), une population sombre (Draveil) et chez les Fl réciproques.

Les mouches ont été étudiées par 3 observateurs indépendants.

Pour chaque génotype et température,

les résultats obtenus pour les mâles et les femelles et les différents observateurs ont été réunis. 
curve of trident. The experiment was done on a dark strain from Draveil (near Paris, France) and on a light strain from Brazzaville (Congo). Results given in figure 3 show that the 2 strains reacted in a similar way and their response curves were almost parallel. Pigmentation was minimum at about $25-28{ }^{\circ} \mathrm{C}$ and increased at higher and lower temperatures, producing a U-shaped curve. Since the left hand part of the curve is more extended than the right hand one, much darker flies are observed at low than high temperatures. From these data we can conclude that for the characterization of any natural population, the results at 2 growth temperatures, 17 and $25^{\circ} \mathrm{C}$ will be sufficient.

\section{B. Analysis of $\mathrm{Fl}$ progeny between dark and light strains}

The 2 natural populations of Draveil and Brazzaville were crossed and the results of the reciprocal Fl's are also shown in figure 3. All the Fl values but one lie between the parental scores. As shown in this figure a clear difference exists at all temperatures between reciprocal progeny : the flies from a light mother (Brazzaville) are less pigmented than flies from a dark mother (Draveil). Such a difference has been confirmed by 3 independant observers. In figure 3 data on both sexes were pooled for clarity. However among Fl individuals, a genetic difference exists between males since they get their X-chromosome from their mother. A difference between the 2 Fl's could be due to a sex-linked gene and as mentioned in the introduction, at least one gene known to influence trident pattern (pentagon) is carried by the $\mathrm{X}$. We thus considered the male and the female Fl's separately and found them very similar. More precisely, if we consider the scores obtained by 3 observers for 6 temperatures, 17 estimates of the difference between reciprocal Fl's were available. Calling the progeny from $q$ Draveil $\delta$ Brazzaville, Fl A, and the reciprocal Fl B, all differences were positive in females with an average of $0.316 \pm 0.097$. An almost identical difference was found for the males $(0.295 \pm 0.117)$. It appears therefore that a maternal effect could be responsible for the difference between reciprocal Fl's.

A final problem is to consider the position of the $\mathrm{Fl}$ with respect to the mid-parent curve. As shown in figure 3 light trident tends to be dominant at high temperatures whereas dark tends to be dominant at the cold ones.

\section{Geographic variation of trident pigmentation}

Recently collected populations from various parts of the world were scored for their trident pigmentation and the results are given in table 2.

If we compare the 2 sexes in the same population we note that their scores are highly correlated ( $\mathrm{r}=0.97$ and 0.98 at 17 and $25^{\circ} \mathrm{C}$ respectively). If we consider for each population the difference $d$ between female and male, we found $d=.003 \pm .027$ at $17^{\circ} \mathrm{C}$ and $d=.100 \pm .015$ at $25^{\circ} \mathrm{C}$. This last value is significantly different from zero and indicates that at $25^{\circ} \mathrm{C}$ females were darker than males. This sex-difference remains however small when populations of various origins are compared so that the average value of both sexes appears a convenient estimate of the properties of any natural population.

As indicated previously we observed that populations from high latitude were generally darker than those living in warmer places. Pigmentation scores plotted in 
TABLE 2

Geographic origin and pigmentation score at 2 temperatures

in various natural populations.

Origine géographique et score de pigmentation

étudié à 2 températures de diverses populations naturelles.

\begin{tabular}{|c|c|c|c|c|c|c|c|c|}
\hline \multirow{2}{*}{ Localities } & \multirow{2}{*}{ Date } & \multirow{2}{*}{ Latitude } & \multicolumn{3}{|c|}{$25 \mathrm{cC}$} & \multicolumn{3}{|c|}{$17 \mathrm{cC}$} \\
\hline & & & q & $\sigma^{*}$ & d & $q$ & $\sigma^{\pi}$ & d \\
\hline \multicolumn{9}{|l|}{ France } \\
\hline Draveil & $9 / 83$ & 48.6 & 0.76 & 0.61 & +0.15 & 2.06 & 2.02 & +0.04 \\
\hline Quimperlé & $8 / 83$ & 47.6 & 0.81 & 0.64 & +0.17 & 2.26 & 2.26 & 0.00 \\
\hline Grandlieu ...... & $10 / 82$ & 47.0 & 0.88 & 0.66 & +0.22 & 1.98 & 1.62 & +0.36 \\
\hline Pornic . ....... & $10 / 82$ & 47.0 & 1.18 & 0.93 & +0.25 & 2.12 & 2.13 & -0.01 \\
\hline Villeurbanne $\ldots$ & $9 / 82$ & 45.5 & 1.22 & 0.94 & +0.28 & 1.97 & 1.72 & +0.25 \\
\hline Villeurbanne ... & $6 / 83$ & 45.5 & 1.32 & 0.96 & +0.36 & 2.38 & 2.29 & +0.09 \\
\hline Villeurbanne ... & $11 / 83$ & 45.5 & 0.90 & 0.76 & +0.14 & 2.09 & 2.16 & -0.07 \\
\hline Moulis ........ & $9 / 83$ & 43.5 & 0.72 & 0.68 & +0.04 & 1.92 & 1.86 & +0.06 \\
\hline Porquerolles .... & $9 / 83$ & 43.0 & 0.35 & 0.34 & +0.01 & 1.56 & 1.61 & -0.05 \\
\hline \multicolumn{9}{|l|}{ Spain } \\
\hline Barcelona & $10 / 83$ & 41.3 & 1.12 & 1.00 & +0.12 & 2.14 & 2.18 & -0.04 \\
\hline Sevilla $\ldots \ldots \ldots$ & $5 / 83$ & 37.5 & 0.30 & 0.23 & +0.07 & 1.19 & 1.43 & -0.24 \\
\hline \multicolumn{9}{|l|}{ Greece } \\
\hline Athens & $8 / 82$ & 38.0 & 0.33 & 0.33 & 0.00 & 1.18 & 1.24 & -0.06 \\
\hline Athens $\ldots$ & $1 / 83$ & 38.0 & 0.44 & 0.47 & -0.03 & 1.40 & 1.19 & +0.21 \\
\hline Athens $\ldots$ & $4 / 83$ & 38.0 & 0.33 & 0.31 & +0.02 & 1.70 & 1.96 & -0.26 \\
\hline \multicolumn{9}{|l|}{ Tunisia } \\
\hline Bizerte .. & $11 / 83$ & 37.3 & 0.33 & 0.22 & +0.11 & 1.03 & 1.07 & -0.04 \\
\hline Chebika & $11 / 82$ & 35.0 & 0.09 & 0.05 & +0.04 & 0.59 & 0.75 & -0.16 \\
\hline Gafsa & $11 / 82$ & 34.5 & 0.07 & 0.06 & +0.01 & 0.81 & 0.97 & -0.16 \\
\hline Gabès .... & $11 / 82$ & 34.0 & 0.06 & 0.07 & -0.01 & 0.69 & 0.69 & 0.00 \\
\hline Sierra Leone & & & & & & & & \\
\hline Freetown & $7 / 83$ & 8.0 & 0.15 & 0.06 & +0.09 & 1.09 & 1.12 & +0.03 \\
\hline \multicolumn{9}{|l|}{ Ivory Coast } \\
\hline Lamto ... & $2 / 83$ & 7.0 & 0.38 & 0.28 & +0.10 & 0.83 & 0.98 & -0.15 \\
\hline Таї ..... & $2 / 83$ & 5.0 & 0.64 & 0.47 & +0.20 & 1.87 & 1.65 & +0.22 \\
\hline \multicolumn{9}{|l|}{ Bénin } \\
\hline Cotonou & $7 / 83$ & 6.5 & 0.39 & 0.17 & +0.22 & 1.02 & 0.86 & +0.16 \\
\hline \multicolumn{9}{|l|}{ Kenya } \\
\hline Nairobi ... & $1 / 83$ & 1.0 & 0.31 & 0.26 & +0.05 & 1.13 & 0.92 & +0.21 \\
\hline \multicolumn{9}{|l|}{ Congo } \\
\hline Brazzaville .... & $12 / 81$ & 4.0 & 0.00 & 0.00 & 0.00 & 0.26 & 0.20 & +0.06 \\
\hline Brazzaville .... & $4 / 83$ & 4.0 & 0.12 & 0.06 & +0.06 & 0.94 & 0.93 & +0.01 \\
\hline \multicolumn{9}{|l|}{ West Indies } \\
\hline Martinique & $8 / 82$ & 14.3 & 0.02 & 0.03 & -0.01 & 0.51 & 0.48 & +0.03 \\
\hline Guadeloupe .... & $2 / 82$ & 16.0 & 0.00 & 0.00 & 0.00 & 0.12 & 0.24 & -0.12 \\
\hline Guadeloupe .... & $2 / 83$ & 16.0 & 0.10 & 0.04 & +0.06 & 0.58 & 0.64 & -0.06 \\
\hline Porto Rico ..... & $2 / 83$ & 18.0 & 0.35 & 0.27 & +0.08 & 1.34 & 1.72 & -0.38 \\
\hline \multicolumn{9}{|l|}{ Seychelles } \\
\hline Mahé & $10 / 81$ & 4.0 & 0.12 & 0.09 & +0.03 & 0.73 & 0.67 & +0.06 \\
\hline \multicolumn{9}{|l|}{ Australia } \\
\hline Melbourne & $1 / 83$ & 37.7 & 0.91 & 0.61 & +0.30 & 1.49 & 1.46 & +0.03 \\
\hline Melbourne & $6 / 83$ & 37.7 & 0.81 & 0.70 & +0.09 & 1.94 & 1.82 & +0.12 \\
\hline
\end{tabular}


relation to latitude of origin are given in figure 4 . Results obtained at $17^{\circ} \mathrm{C}$ and $25{ }^{\circ} \mathrm{C}$ are quite similar. Each figure can be divided into 2 parts : one for latitudes below $20^{\circ}$ (tropical populations) and another for latitude above $30^{\circ}$ (temperate populations). No populations were available between $20^{\circ}$ and $30^{\circ}$.

A large amount of variability is observed in tropical populations and no general trend is found between pigmentation and latitude. Such heterogeneity exists even between populations from the same continent. For example, in tropical Africa the population of Brazzaville was repeatedly found very light while that of the Tai forest (Ivory coast) was especially dark. In the neotropical region we notice very light populations from French Antilles while a dark population was collected in Porto-Rico.

By constrast, temperate populations, living at latitudes above $30^{\circ}$, exhibit a very steep cline. Between $34^{\circ}$ and $48^{\circ}$, the score increases from 0.1 to more than 1.1 at $25^{\circ}$ and from 0.7 to 2.2 at $17^{\circ}$. This allows for example a clear separation between French and Greek populations and between Greek and Tunisian ones. Moreover the cline seems to occur in both hemispheres since Australian populations are not very different from the Greek ones.

A last point to mention is the observation of a fairly large variability between proximate populations or between successive samples taken from the same locality. For example the various samples from Villeurbanne produced quite different scores. For the moment we cannot decide if such differences reflect scoring fluctuations or true genetic variations. Further investigations are needed to analyse microgeographic differentiations or seasonal variations.

\section{Discussion and conclusion}

Many adult phenotypic traits in Drosophila as in other insects, vary according to growth temperature and the shape of the response curves may be quite diverse according to the trait which is considered (see DAvID et al., 1983 ; for a review). With respect to pigmentation it was known for a long time that development at a low temperature would produce darker flies. Ecologists mentioned that for several species winter or spring generations were darker than summer flies. Nevertheless no precise description of this phenomenon existed even in $D$. melanogaster, due to difficulties in quantification of these phenotypic differences. Thoracic trident is not the only color trait which is influenced by temperature and in D. melanogaster the extension of the dark spots on the tergites of female abdomen also depends on growth conditions (ROBERTSON et al., 1977). We have shown here that variations in trident pigmentation between samples of flies can be described in a reproducible way due to the establishment of phenotypic classes. This allows the analysis of physiological responses and of genetic divergences.

The temperature response of trident pigmentation exhibits a $U$ shaped curve with a minimum at $25^{\circ} \mathrm{C}$. Such a shape appears, for the moment, unique among all these which have already been described for morphological or physiological traits (DAvID et al., 1983).

Differences between populations, when grown under identical controlled laboratory conditions, have a genetic basis, as shown for example in figure 3 . No attempt 


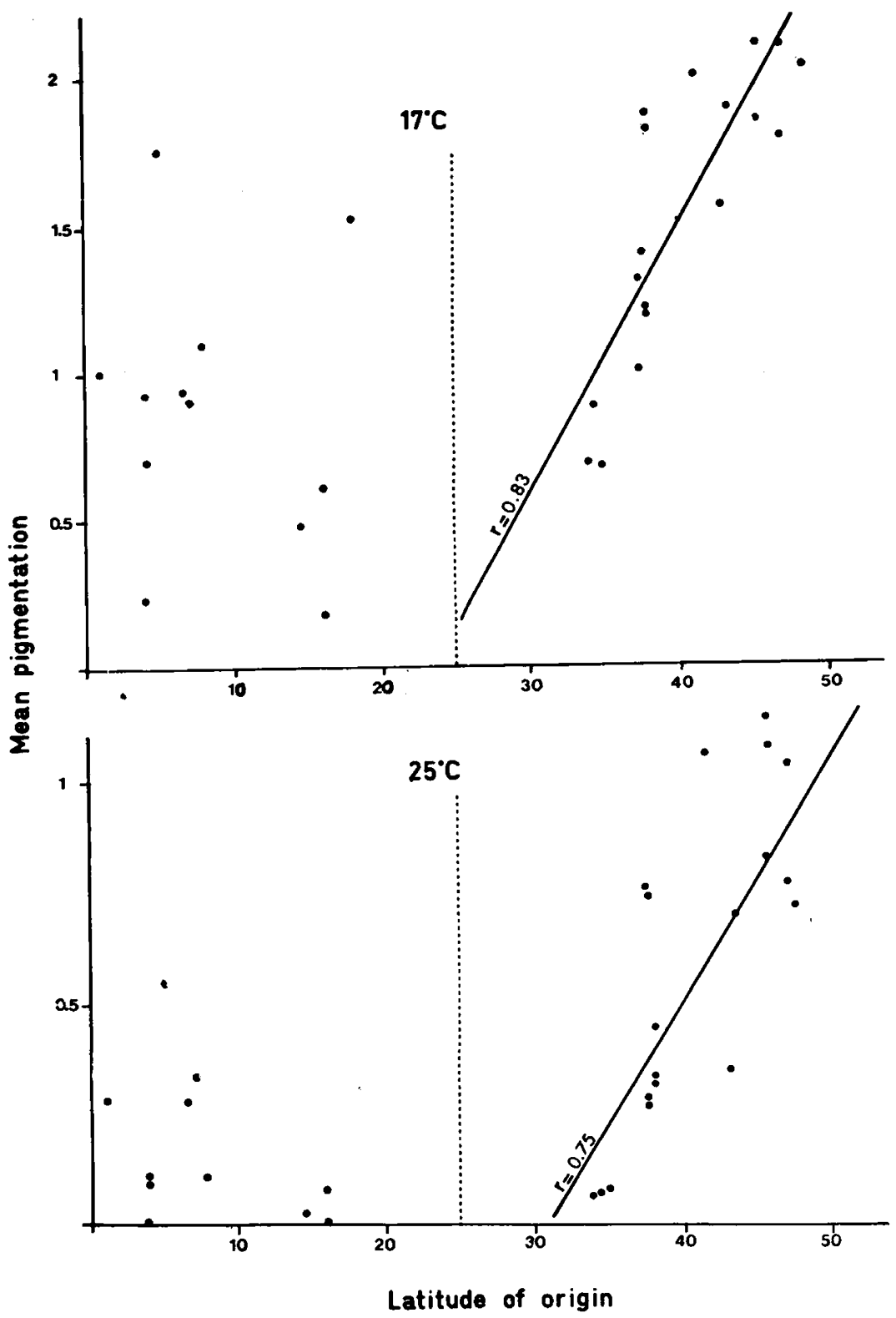

FIG. 4

Relationship between trident pigmentation score and latitude of origin at 17 and $25^{\circ} \mathrm{C}$. Notice the scale difference for the ordinates of the 2 graphs.

Relation entre l'intensité de la pigmentation du trident et la latitude d'origine des souches (développement étudié à 17 et $25^{\circ} \mathrm{C}$ ).

Noter la différence d'échelle pour les ordonnées des 2 graphiques. 
was made in this work to identify the responsible genes nor to get an approximate chromosome localisation. The thoracic trident can be better considered as a quantitative trait determined by several genes on different chromosomes.

A most surprising result is the very clear maternal effect observed in the progeny of a cross between a French and a Congo population. European and Afrotropical populations exhibit a very large amount of genetic differentiation for many different genetical traits (David \& Bocouet, 1975 ; Allemand \& David, 1976 ; David, 1979 ; 1982) and it would be very interesting to find that some kind of cytoplasmic differentiation has also taken place during their divergence. Further investigations are needed to check this hypothesis and also to analyse the physiological basis of this phenomenon.

The latitudinal variation in trident intensity remains the main conclusion of this work. There are apparently no variations according to longitude since Australian populations, for example, are similar to mediterranean ones. Otherwise, no possible altitudinal effect can be considered since all studied populations originated from low places. Many traits exhibit latitudinal clines in D. melanogaster such as morphology (DAvid et al., 1977), physiology (DAvid \& Bocouet, 1975 ; Bouletreau et al., 1982), behavior (Allemand \& DAVID, 1976), allozyme frequencies (DAvid, 1982; OAKESHOtT et al., $1981 \mathrm{a}, \mathrm{b}$ ) or chromosome inversions (METTLER et al., 1977 ; KNIBB, 1982). However, for all these traits the main difference has been observed over a long range geographical scale often several thousands of $\mathrm{km}$. The trident cline described here exhibits by contrast its main variation over a distance of about $1500 \mathrm{~km}$ and appears much steeper. Thorax pigmentation for example distinguishes Greek and French populations which cannot be separated either by morphological analysis or allozyme frequencies (unpublished results).

Genetic variations in pigmentation occur in geographic populations of many species and their significance has been discussed many times. The most ancient ecological rule, i.e. GLOGER's rule, which is especially valid for Vertebrates says that pigmentation will increase with decreasing latitude, assuming that a darker body is protective from sunshine and especially U.V. rays (RENSCH, 1960; MAYR, 1963; Dobzhansky, 1970 ; Dobzhansky et al., 1977 ; Merrel, 1981). In the case of Invertebrates many cases are known and it has generally been found that pigmentation will decrease when temperature or dryness increase, and increase in colder and more humid places. Our data fit this general trend since in temperate countries a lower latitude will be correlated with lower humidity : the aridity of summer in Mediterranean countries is a well known climatic feature.

In the tropics, the above climatic parameters are often related in an opposite way : temperature remains high and stable all year round while humidity, although variable, is also of ten very high. Humidity could therefore be the main selective factor, but other factors may also be considered. Color variations respond to many other environmental pressures than climate, for example sex-recognition or predators (see Merrel, 1981, for discussion). We may recall that the darkest tropical population was collected in the Taï rain forest, i.e. in a dark environment in which a darker body color may help to escape predation. We can also assume that in the tropics body color is basically neutral and that geographic variations reflect mainly founder effects and genetic drift. Such mechanisms were recently argued to explain the " leapfrog " pattern of body color among bird populations in Andean moutains (REMSEN, 1984). 
In temperate places the latitudinal cline is unlikely to be neutral and its significance deserves further investigation. Protection against heat and dessication remains the most likely advantage of light color. Indeed, a latitudinal cline for heat and desiccation tolerance was observed in Australia (PARSONS, 1980) altough the phenotypes of the flies were not mentioned. In another species (D. melanica) of America, it was already known that populations living in arid semidesert environment were much lighter than those from forest habitats (WARD, 1958). Physiological studies have shown that internal temperature was higher in dark trident flies after a solar-type radiation and also that $\beta$-alanine, which is involved in the production of a tan (not dark) pigment, enhanced cuticular toughness. On the other hand dark ebony flies were found to be less tolerant to desiccation than normal ones (JAcoBs, 1968). Analysis of physiological-biochemical differences should help to elucidate the significance of trident variations in natural populations.

\section{Acknowledgements}

We thank Drs. M. JAcoBs \& A. Robertson for help and comments on the manuscript and also Drs. B. Burnet, Y. Carton, D. Lachaise, J. McKechnie, A. Prevosti, J. RenouX \& J. VouidiBio for providing natural populations.

Received September 10, 1984.

Accepted November 23, 1984.

\section{References}

Allemand R., David J.R., 1976. The circadian rhythm of oviposition in Drosophila melanogaster : A genetic latitudinal cline in wild populations. Experientia, 32, 1403-1404.

Bouletreau-Merle J., Allemand F., Cohet Y., David J.R., 1982. Reproductive strategy in Drosophila melanogaster: significance of a genetic divergence between temperate and tropical populations. Oecologia, 53, 323-324.

Capy P., David J.R., Allemand R., Hyytia P., Rouault J., 1983. Genetic properties of North African Drosophila melanogaster and comparison with European and Afrotropical populations. Génét. Sél. Evol., 15, 185-200.

DAVID J.R., 1979. Utilization of morphological traits for the analysis of genetic variability in wild populations. Aquilo, (Ser. Zool.), 20, 49-61.

DAvid J.R., 1982. Latitudinal variability of Drosophila melanogaster : allozyme frequencies divergence between and Afrotropical populations. Biochemical Genetics, 20, 747-761.

David J.R., Allemand R., Van Herrewege J., Cohet Y., 1983. Ecophysiology : abiotic factors. In AshbuRner M., CARSON H.L. and THOMPSON J.N. Jr. (ed.), The genetics and biology of Drosophila, 105-170, Vol. 3 d, Acad. Press, New York.

David J.R., BocQuet C., 1975. Similarities and differences in latitudinal adaptation of two Drosophila sibling species. Nature, 257, 588-590.

David J.R., Bocquet C., De Scheemaeker-Louis M., 1977. Genetic latitudinal adaptation of Drosophila melanogaster : new discriminative biometrical traits between European and Equatorial African populations. Genet. Res., Camb., 30, 247-255.

David J.R., Clavel M.F., 1965. Interaction entre le génotype et le milieu d'élevage. Conséquences sur les caractéristiques du développement de la Drosophile. Bull. Biol. Fr. Belg., 99, 369-378. 
Dobzhansky T., 1970. Genetics of the evolutionary process. 505 pp., Columb. Univ. Press., New York.

Dobzhansky T., Ayala F., Stebbins G.L., Valentine J.W., 1977. Evolution. 572 pp., Freeman and Co, San Francisco.

JACOBS M.E., 1960. Influence of light on mating of Drosophila melanogaster. Ecology, 41, 182-188.

JACOBS M.E., 1968. Beta-alanine used by ebony and normal Drosophila melanogaster with notes on glucose, uracil, dopa and topanine. Biochem. Genet., 1, 267-275.

JACOBS M.E., 1974. Beta-alanine and adaptation in Drosophila. J. Insect Physiol., 20, 859-866.

JACOBS M.E., 1976. Binding of beta-alanine, dopamine and dopa 1.C.14 by normal, ebony and dark Drosophila melanogaster cuticles. Insect Biochem., 6, 497-499.

JACOBS M.E., 1978. Influence of $\beta$-alanine on mating and territorialism in Drosophila melanogaster. Behavior Genetics, 8, 487-502.

JACOBS M.E., 1982. Beta-alanine and tanning polymorphisms. Comp. Biochem. Physiol., 72 B, $173-177$.

KNIBB W.R., 1982. Chromosome inversion polymorphisms in Drosophila melanogaster. II. Geographic clines and climatic associations in Australasia, North America and Asia. Genetica, 58, 213-221.

Lemeunier F., David J.R., Tsacas L., Ashburner M., 1985. The D. melanogaster species group. In Ashburner M., Carson H.L. and Thompson J.N. Jr. (ed.), The genetics and biology of Drosophila, Vol. 3, Acad. Press. New York (in press).

LindSley D.L., Grell E.H., 1968. Genetic variations of Drosophila melanogaster. Carnegie Inst. Wash. Publ. $\mathrm{n}^{\circ} 627$.

MAYR E., 1963. Animal species and evolution. 642 pp., Harvard Univ. Press, Cambridge, Mass.

Merrel D.J., 1981. Ecological genetics. 500 pp., Longman, London.

MetTler I.E., Voelker R.A., MukaI T., 1977. Inversion cline in populations of Drosophila melanogaster. Genetics, 87, 169-176.

MoRgan T.H., BRidges C.B., 1919. The inheritance of a fluctuating character. J. Gen. Physiol., 1, 639-643.

Oakeshott J.G., Chambers G.K., Gibson J.B., Willcoks D.A., 1981 a. Latitudinal relationship of esterase-6 and phosphoglucomutase gene frequencies in Drosophila melanogaster. Heredity, 47, 385-396.

Oakeshott J.G., Gibson J.B., Anderson P.R., KnibB W.R., Anderson D.G., Chambers G.K., 1981 b. Alcohol dehydrogenase and Glycerol-3 phosphate dehydrogenase cline in Drosophila melanogaster on different continents Evolution, 36, 86-96.

Parsons P.A., 1980. Parallel climatic races for tolerance to high temperature dessication stress in two Drosophila species. J. Biogeogr., 7, 97-101.

REMSEN J.V. Jr., 1984. High incidence of «leapfrog» pattern of geographic variation in Andean birds : implication for the speciation process. Science, 224, 171-172.

ReNsch B., 1960. Evolution above the species level. 231 pp., Columb. Univ. Press. New York.

Robertson A., Briscoe D.A., Louw J.H., 1977. Variation in abdomen pigmentation in Drosophila melanogaster females. Genetica, 47, 73-76.

Ward C.L., 1952. Chromosome variation in Drosophila melanica. Univ. Texas Publ., 5204, 237-257. 